\title{
A case of chickenpox complicated with subacute osteomyelitis
}

\author{
Subakut osteomyelit komplikasyonu gelişen bir suçiçeği olgusu
}

Mustafa ÇAKAN, Nuray AKTAY AYAZ, Timur YILDIRIM, Hamide Sevinç GENÇ, Ali ER, Gonca KESKINDEMİRCi

\begin{abstract}
Chickenpox is a viral disease characterized by vesicular skin eruptions. It is commonly encountered during childhood and generally follows a benign course without complications. The most common complications are secondary bacterial skin infections ranging from superficial impetigo to subcutaneous abscess. Musculoskeletal complications like septic arthritis and osteomyelitis are rarely seen. In any child complaining of bone pain or arthralgia, during or after healing of varicella eruptions, the possibility of osteomyelitis and septic arthritis should be kept in mind. Early diagnosis is important because with the use of appropriate antibiotics, the need for surgical interventions and sequela can be prevented. Here, we present a case of subacute osteomyelitis that needed antibiotic and surgical treatment, whose initial symptom was right ankle pain that developed after three weeks of chicken pox.
\end{abstract}

Keywords: Chickenpox, Child, Complication, Osteomyelitis

Mustafa Çakan (四), Nuray Aktay Ayaz

Pediatric Rheumatology Clinic, Kanuni Sultan Süleyman Training and Research Hospital, Istanbul, Turkey

e-mail: mustafacakan@hotmail.com

Timur Yildırım

Orthopedics Clinic, Metin Sabancı Baltaliman Bone Diseases Training and Research Hospital, Istanbul, Turkey

Hamide Sevinç Genç, Gonca Keskindemirci

Pediatric Clinic, Kanuni Sultan Süleyman Training and Research Hospital, Istanbul, Turkey

Ali Er

Radiology Clinic, Kanuni Sultan Süleyman Training and Research Hospital, Istanbul, Turkey

Submitted/Gönderme: 22.12 .2015

Accepted/Kabul: 03.02.2016
ÖZ

Suçiçeği, çocukluk çağında sık görülen ve genellikle komplikasyonsuz seyreden, veziküler döküntüler ile karakterize viral bir hastalıktır. En s1k görülen komplikasyonlar yüzeyel impetigodan, subkütan abseye kadar değişebilen sekonder bakteriyel deri infeksiyonlarıdır. Septik artrit ve osteomyelit gibi muskuloskeletal komplikasyonlar ise çok nadir görülen komplikasyonlardır. Suçiçeği sırasında veya döküntüler iyileştikten sonra eklem veya kemik ağrısından şikayet eden tüm çocuklarda osteomyelit veya septik artrit olasılığı akılda tutulmalıdır. Uygun antibiyotik tedavisi ile cerrahi müdahale veya sekel oranı belirgin azaldığı için erken tanı önemlidir. Bu yazıda suçiçeğinden üç hafta sonra ayak bileği ağrısı şikayeti gelişen ve subakut osteomyelit tanisı konularak antibiyotik ve cerrahi tedavi uygulanan olgu sunulmuştur.

Anahtar kelimeler: Suçiçeği, Çocuk, Komplikasyon, Osteomyelit

\section{Introduction}

Chickenpox is a common viral disease during childhood and is characterized by vesiculobullous eruptions that generally follows a benign course [1]. Newborns and infants and elderly people are the most vulnerable age groups for complications. In children with underlying immunodeficiency both complication and mortality rates are high [2]. The most common complications are secondary bacterial skin infections ranging from superficial impetigo to subcutaneous abscesses. The other relatively common complications are encephalitis, cerebellar ataxia, pneumonia, hepatitis and thrombocytopenia. Musculoskeletal complications like septic arthritis and osteomyelitis are rarely seen [3-5]. Osteomyelitis is the inflammation of the bone tissue caused by bacterial or fungal microorganisms and classified as acute, subacute and chronic depending on 
the duration of the symptoms. Metaphysis of the long tubular bones like femur, tibia and humerus are the most common locations. Hematogenous seeding of the microorganism is the most common way of inoculation. When compared with acute osteomyelitis, in subacute osteomyelitis the duration of the disease is longer (more than two weeks), pain is less severe, and generally fever is absent [6].

\section{Case Report}

An 11-year-old boy was admitted to our hospital with the complaint of pain and swelling around the right ankle for the last three weeks. It was learned that he had chickenpox one month ago and the eruptions healed in two weeks. As the child had pain on the right ankle, the family consulted a pediatrician and he was referred to pediatric rheumatologist with the initial diagnosis of reactive arthritis secondary to chickenpox. On physical examination, the skin integrity was intact on the whole body and there were a few healed chickenpox eruptions but there was not any pain, effusion, hyperemia, warmth or restriction of movement on the right ankle. There was edema, warmth, pain by palpation on the upper medial part of the right ankle (Fig. 1). The physical examination was otherwise unremarkable. He was born as triplet on the $34^{\text {th }}$ week of gestation with the birth weight of 1350 gr. He had a 10 day history of hospitalization postnatally. He had never been hospitalized since then and the family denied any recurrent infection episodes.

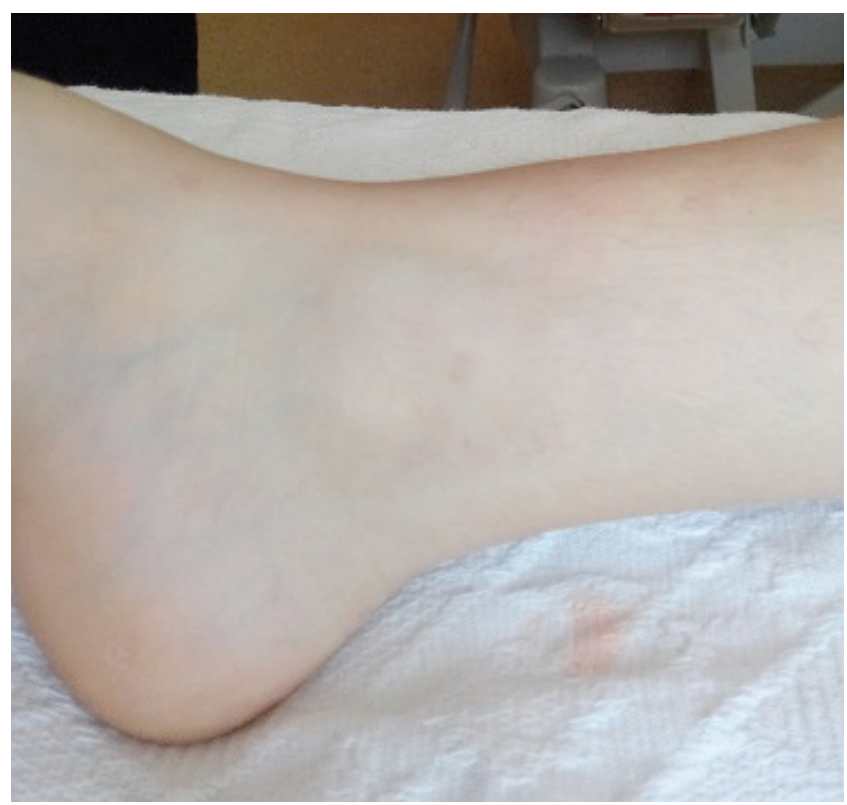

Fig. 1. The view of the minimal edema on the skin of upper medial part of the right ankle
On laboratory tests leukocyte count was $11.400 / \mathrm{mm}^{3}$, erythrocyte sedimentation rate was $67 \mathrm{~mm} / \mathrm{hr}$ (normal: $<15$ $\mathrm{mm} / \mathrm{hr}$ ) and C-reactive protein (CRP) was $26 \mathrm{mg} / \mathrm{L}$ (normal: 0-5 mg/L). Peripheral blood smear was normal. On the $\mathrm{X}$-ray of the right ankle, radiolucency on the metaphysis and minimal periosteal reaction on the distal tibia was seen. Erosion in the cortical bone was not observed at the level of the lesion (Fig. 2). On magnetic resonance imaging (MRI), lesion extending from diaphysiometaphyseal region to epiphyseal region of the medullary bone of the distal tibia was observed. On T1-weighted images the lesion had central iso-hypointense image (compatible with fluid) surrounded by circular hypointense rim (Fig. 3a). On fat-suppressed T2-weighted images, central part of the lesion was hyperintense and the surrounding soft tissue had a heterogeneous hyperintense image compatible with inflammation (Fig. 3b). On the contrasted images, the lesion had heterogeneous contrast enhancement (Fig. $3 \mathrm{c})$. The clinical picture of the patient was discussed with orthopedic surgeon and as the child had high acute phase reactants with no fever, history of a recent chickenpox infection and radiological images were more suggestive of an infectious process, initiation of antibiotic treatment with the diagnosis of subacute osteomyelitis was recommended. Intravenous cefazolin and clindamycin was commenced after obtaining blood and urine cultures. On the initial and repeated blood cultures no microorganism was isolated. As musculoskeletal complications after chickenpox infection are more commonly observed in immunocompromised individuals, plasma immunoglobulin and lymphocyte subtype levels were studied and found normal. On the $2^{\text {nd }}$ week of treatment, acute phase reactants were still high and local findings did not improve much so antibiotic treatment was changed to teicoplanin. With this treatment laboratory and clinical findings of the patient improved. On the $6^{\text {th }}$ week of treatment, control MRI study was conducted and it was seen that the size of the lesion was regressed minimally but periosteal reaction and pathological signal intensities of the medullary bone were still persisting. To rule out primary bone tumors (especially Ewing sarcoma) biopsy was taken from the lesion. On the pathological examination no malignant cells were observed but proliferation of the connective tissue cells with partially degenerated bone tissue was seen. Ehrlich-Ziehl-Neelsen staining was negative and cultures for bacteria and M. tuberculosis were sterile. Antibiotic treatment was given for 8 weeks and debridement of the lesion was made. The patient is being followed for 2 years without any complication. 


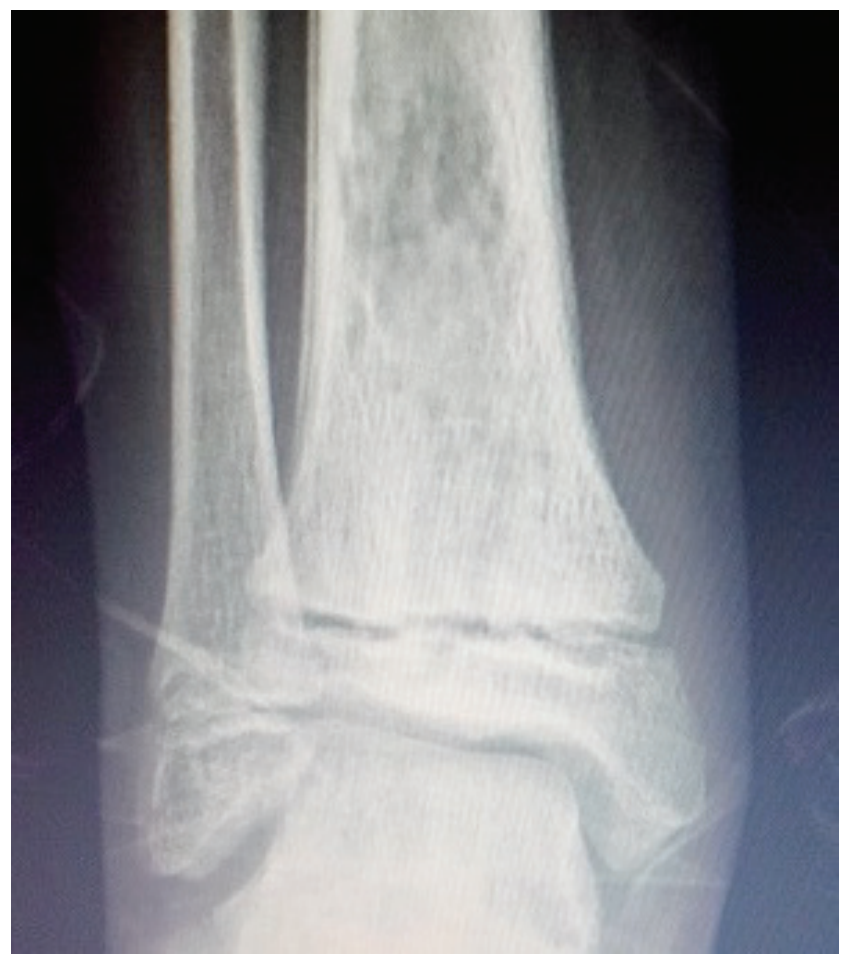

Fig. 2. The view of the radiolucency and minimal periosteal reaction on the metaphysis of the distal tibia

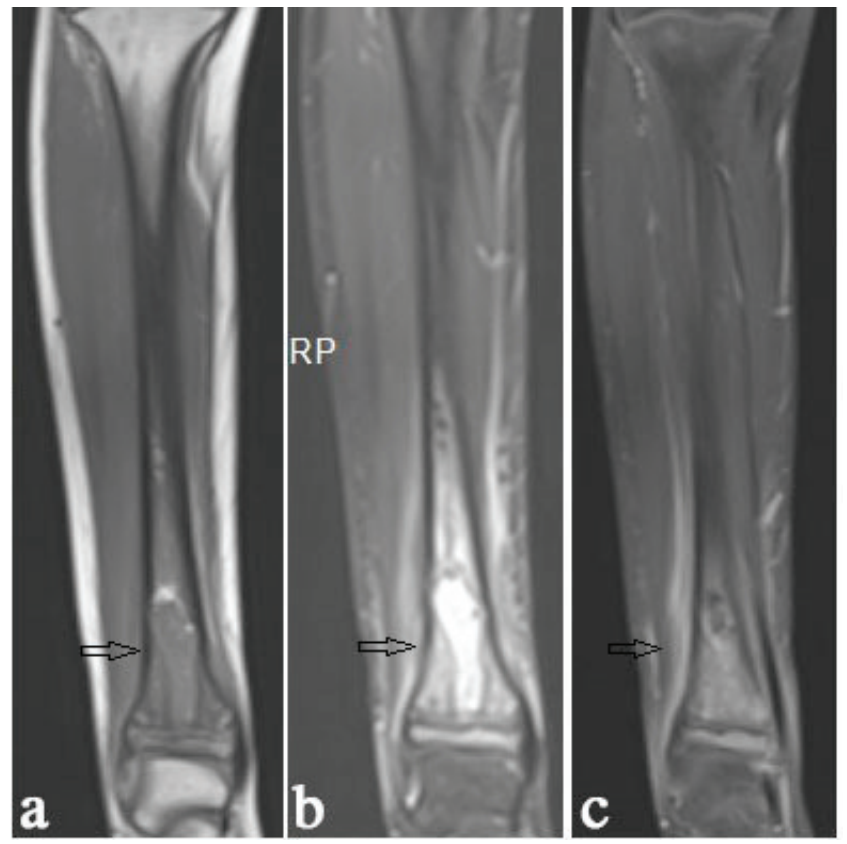

Fig. 3. The view of the lesion on MRI (3a: T1-weighted, 3b: T2weighted, $3 \mathrm{c}$ : contrasted images

\section{Discussion}

The most common complication of the chickenpox is secondary bacterial infection of the skin and soft tissue.
It is observed in $2-5 \%$ of all chickenpox cases [2,3]. The other possible complications of the disease are pneumonia, encephalitis, cerebellar ataxia, hepatitis, thrombocytopenia, myocarditis, pancreatitis and nephritis [3-5]. Hospitalizations due to chickenpox are related to complications and found to be 6-10/100.000 in two different studies that are made in our country $[7,8]$.

Subacute osteomyelitis definition is used to describe osteomyelitis cases with longer duration of the symptoms (more than 2 weeks), with no fever and less severe local pain and with relatively high acute phase reactants [6]. Our case had symptoms for 3 weeks, no fever and elevated acute phase reactants that were compatible with this definition. Septic arthritis or osteomyelitis secondary to chickenpox infection is an extremely rare entity. In the study of Koturoglu et al., $1(0.5 \%)$ case of osteomyelitis was found in 178 cases with chickenpox complications [4]. In the series of Ziebold et al., $4(3.3 \%)$ cases of osteomyelitis were found in 119 patients [5]. Metaphysis of the long bones is the usual location for osteomyelitis [6]. As the causative agent, S. pyogenes is the most common agent in osteomyelitis cases secondary to chickenpox infection while in cases not related to chickenpox, S. aureus is the most common agent $[9,10]$. The rate of yielding a microorganism in blood cultures in acute osteomyelitis cases is around $30-50 \%$, but as in our case, in subacute cases this is very low $[6,11]$. If subperiosteal fluid collection or abscess formation is detected on the initial imaging modalities aspiration for both diagnosis and treatment is recommended. The rate of demonstrating a causative agent with this method increase up to $70-80 \%$ [6,9-11]. Since there was no subperiosteal fluid collection or abscess formation in our case, aspiration and culture from the lesion was not performed before starting antibiotic treatment.

During early phases of the disease, cortical reaction and mineralization defects can be seen on the X-rays. Since MRI examination gives much more information about nature of the lesion, it is recommended to all cases with suspected osteomyelitis. It is seen that medullary fat tissue is replaced by bone marrow edema. Other MRI findings that can be seen in osteomyelitis are periosteal reaction, subperiosteal fluid collection, bone destruction and surrounding soft tissue changes $[9,12]$. In our case, on the X-rays minimal periosteal reaction and mineralization irregularity were seen on the diaphysiometaphyseal region of the distal tibia. On the MRI examination edema in the bone marrow and surrounding soft tissue was observed. Hence it is hard to 
discriminate malignant bone tumors like Ewing sarcoma and osteosarcoma from subacute and chronic osteomyelitis solely by clinical and radiological findings, biopsy is recommended if appropriate response is not reached after antibiotic treatment $[13,14]$. In the study of Shimose et al., all 244 cases that had initial diagnosis of bone tumor were histologically examined and it was seen that 15 cases had subacute/chronic osteomyelitis, 83 cases had malignant, 77 cases had benign bone tumors and 69 cases had tumor-like lesions [14]. Sensitivity and specificity of the elevated CRP for osteomyelitis was found $60 \%$ and $90.8 \%$, respectively [14]. Penumbra sign is defined on T1-weighted images as a higher signal intensity because of the thin layer of granulation tissue that lines the lesion. The sensitivity of the penumbra sign for osteomyelitis was $77.3 \%$ and specificity was 99.1\% [14]. In our case high CRP level and the presence of penumbra sign (Fig. 3a) support this opinion.

In cases of acute osteomyelitis early initiation of antibiotic treatment will be generally enough but in cases of subacute osteomyelitis surgical intervention is generally needed. As initial treatment, an intravenous antibiotic from cephalosporin group is recommended. Modifications with clindamycin, teicoplanin or linezolid are recommended in cases that are not responsive. Four to six weeks of treatment is suggested in uncomplicated cases but in cases that needed surgery 8 weeks of treatment is recommended $[6,10,15]$. In the study of Hamdy et al., a total of 44 cases of subacute osteomyelitis were treated and 24 of them were treated only with antibiotics and 20 of them were treated with antibiotics and debridement. After 18 months of follow-up no difference was found in the remission and recurrence rates and the authors suggested that subacute osteomyelitis cases should be initially treated with antibiotic treatment and surgical debridement should be applied if remission is not observed on control imaging studies [16]. In our case, after 6 weeks of antibiotic treatment minimal remission was achieved on control images and debridement was made and antibiotic treatment was completed to 8 weeks.

In conclusion, in any child complaining of joint or bone pain, or limping during or after chickenpox infection, the possibility of osteomyelitis or septic arthritis should be kept in mind. As appropriate treatment will possibly yield healing without complication early recognition and multidisciplinary approach is essential.

\section{References}

1. Mueller NH, Gilden DH, Cohrs RJ, Mahalingam R, Nagel MA.Varicella zoster virus infection: clinical features, molecular pathogenesis of disease, and latency. Neurol Clin 2008;26:675-97, doi: 10.1016/j.ncl.2008.03.011.

2. Choo PW, Donahue JG, Manson JE, Platt R. The epidemiology of varicella and its complications. J Infect Dis 1995;172:706-12.

3. Aebi C, Ahmed A, Ramilo O. Bacterial complications of primary varicella in childdren. Clin Infect Dis 1996;23:698705.

4. Koturoglu G, Kurugöl Z, Cetin N, et al. Complications of varicella in healthy children in Izmir, Turkey. Pediatrics International 2005;47:296-9.

5. Ziebold C, von Kries R, Lang R, Weigl J, Schmitt HJ. Severe complications of varicella in previously healthy children in Germany: a 1-year survey. Pediatrics 2001;108: E79.

6. Laxer RM, Lindsey CB. Arthritis related to infection. In: Cassidy JT, Petty RE, Laxer RM, Lindsey CB, editors. Textbook of Pediatric Rheumatology. 6th ed. Philadelphia: Saunders, 2011:559-78.

7. Dinleyici EC, Kurugol Z, Turel O, et al. The epidemiology and economic impact of varicella-related hospitalizations in Turkey from 2008 to 2010: a nationwide survey during the prevaccine era (VARICOMP study). Eur J Pediatr 2012;171:81725. doi: 10.1007/s00431-011-1650-z.

8. Özdemir H, Çandır MO, Karbuz A, et al. Chickenpox complications, incidence and financial burden in previously healthy children and those with an underlying disease in Ankara in the pre-vaccination period. Turk $\mathrm{J}$ Pediatr 2011;53:614-25.

9. Borgen L, Haakonsen MO, Gudmundsen TE, Solheim $\mathrm{D}$, Stensvold K. Acute osteomyelitis as a complication of varicella. Acta Radiol 2005;46:652-6.

10. Bozzola E, Krzystofiak A, Lancella L, Quondamcarlo A, Villani A. A severe case of paediatric group A streptococcal osteomyelitis in varicella. Infection 2012;40:343-5. doi: 10.1007/s15010-011-0195-4.

11. McCarthy JJ, Dormans JP, Kozin SH, et al. Musculoskeletal infections in children: basic treatment principles and recent advancements. J Bone Joint Surg Am 2004; 86:850-63.

12. Kaplan PA, Helms CA, Dussault R, Anderson MW, Major NM. Muskuloskeletal infections. In: Musculoskeletal MRI. 1st ed. Philadelphia: Saunders: 2001.

13. Cottias P, Tomeno B, Anract P, Vinh TS, Forest M. Subacute osteomyelitis presenting as a bone tumour. A review of 21 cases. Int Orthop 1997;21:243-8.

14. Shimose $S$, Sugita $T$, Kubo $T$, Matsuo $T$, Nobuto $H$, Ochi M. Differential diagnosis between osteomyelitis and bone tumors. Acta Radiol 2008;49:928-33. doi: 10.1080/02841850802241809

15. Bittmann $\mathrm{S}$. Bacterial osteomyelitis after varicella infection in children. J Bone Miner Metab 2004;22:283-5.

16. Hamdy RC, Lawton L, Carey T, Wiley J, Marton D. Subacute hematogenous osteomyelitis: are biopsy and surgery always indicated? J Pediatr Orthop 1996;16:220-3. 